\title{
Pengaruh Ukuran Serbuk Biji Azadirachta Indica Dalam Minyak Kelapa Terhadap Organoleptik
}

\author{
The Effect Of Azadirachta Indica Seed Size In Coconut Oil To The \\ Organoleptic
}

\author{
Siti Zamilatul Azkiyah \\ Program Studi Farmasi, Fakultas Ilmu Kesehatan, Universitas Ibrahimy \\ Email: st.zamilatulazkiyah@ @mail.com
}

\begin{abstract}
ABSTRAK
Nimba (Azadiractha indica) memiliki senyawa metabolit sekunder dominan berupa azadirachtin yang terdapat pada bagian biji. Tujuan penelitian ini untuk mengetahui pengaruh serbuk biji nimba dalam pelarut minyak kelapa terhadap organoleptik. Pada penelitian ini menggunakan metode ekstraksi maserasi dan infus minyak dan hasil organoleptik dianalisis deskriptif kualitatif meliputi warna, aroma dan $\mathrm{pH}$. Berdasarkan hasil penelitian menunjukkan terdapat pengaruh ukuran serbuk biji nimba dalam pelarut minyak kelapa terhadap uji organoleptik. Pada pengamatan warna perlakuan serbuk biji nimba 80 mesh memiliki warna tidak jernih (+++) paling pekat dan kontrol (minyak kelapa) jernih. Hasil pengamatan aroma semua perlakuan dan kontrol tidak tengik. Pada hasil pengukuran $\mathrm{pH}$ semuanya bersifat asam yaitu kontol 5 dan semua perlakuan memiliki pH 6.
\end{abstract}

Kata Kunci: Biji Nimba, Minyak Kelapa, Organoleptik.

ABSTRACT

Neem (Azadiractha indica) has a dominant secondary metabolite compound in the form of azadirachtin found in the seeds. The purpose of this study was to determine the effect of neem seed powder in coconut oil solvents on organoleptics. In this study using maceration and oil infusion extraction methods and organoleptic results were analyzed descriptively qualitatively including color, aroma and $\mathrm{pH}$. Based on the results of the study showed that there was an effect of the size of neem seed powder in coconut oil solvent on organoleptic tests. In the observation of the color treatment of 80 mesh neem seed powder has the most concentrated color $(+++)$ and the clearest (coconut oil) control. The results of the observation of the aroma of all treatments and controls are not rancid. In the pH measurement results are all acidic namely dick 5 and all treatments have a pH of 6.

Keywords: Nimba Seeds, Coconut Oil, Organoleptic.

\section{PENDAHULUAN}

Nimba (Azadirachta indica) merupakan tanaman yang banyak tumbuh di daerah Kabupaten Situbondo dan tersebar di sepanjang pesisir pantai.

$\begin{array}{lll}\text { Tanaman } & \text { Nimba memiliki banyak } \\ \text { manfaat } & \text { yaitu sebagai naungan, } \\ \text { tanaman } & \text { obat, insektisida karena }\end{array}$

memiliki senyawa metabolit sekunder sehingga dapat digunakan sebagai insektisida nabati. (Pramudhito, 2010). Menurut Kardinan dan Ruhnayat (2003), senyawa azadirachtin, selain mampu bekerja sebagai insektisida juga mampu bekerja sebagai fungisida, nematisida, bakterisida, dan antivirus. 
Senyawa aktif yang paling dominan dan bersifat insektisida pada tanaman nimba adalah azadirachtin, senyawa ini termasuk dalam kelompok triterpenoid (Vinoth, 2012). Azadirakthin dapat menimbulkan berbagai pengaruh pada serangga, seperti hambatan aktivitas makan, ketahanan hidup, gangguan perkembangan dan lain sebagainya (Sari dan Suharsono, 2014).

Tanaman Nimba yang dimanfaatkan pada penelitian ini adalah bagian biji. Menurut Schmutterer (1990), kandungan bahan aktif insektisida biji mimba lebih banyak dibandingkan daun. Biji mimba mengandung beberapa komponen aktif pestisida antara lain azadirachtin, salannin, azadiradion, salannol, salanolacetate, 3- deacetyl salannin, 14epoxy-azadiradion, gedunin, nimbenin, dan deacetyl nimbinen. Terdapat 4 senyawa yang diketahui sebagai pestisida yaitu azadirachtin, salannin, nimbinen, dan meliantriol. Senyawa azadirachtin berfungsi sebagai penolak makan, toksikan, dan pengganggu pertumbuhan terhadap berbagai jenis hama dan relatif aman terhadap manusia dan binatang (Thomson, 1992).
Pada saat ini pemanfaatan biji nimba masih sangat kurang dikalang masyarakat terutama di daerah Kabupaten Situbondo. Pemanfaatan biji nimba pada penelitian dilakukan dengan mengekstraksi secara sederhana kandungan yang ada dalam biji nimba menggunakan pelarut minyak kelapa.

Minyak kelapa diperoleh dari tanaman kelapa atau Cocos nucifera L. yaitu pada bagian inti buah kelapa (kernel atau endosperm). Minyak kelapa dapat diperoleh dari daging buah kelapa segar atau dari kopra. Kandungan lemak (minyak) dalam kopra umunya berkisar 60-65 \%. Sedangkan daging buah segar, kandungan minyaknya sekitar $43 \%$ (Suhardiyono, 1995). Warna pada minyak kelapa disebabkan oleh zat warna dan kotoran-kotoran lainnya. Zat warna alamiah yang terdapat pada minyak kelapa adalah karoten yang merupakan hidrokarbon tidak jenuh dan tidak stabil pada suhu tinggi (Tambun, 2006).

Minyak kelapa mengandung $84 \%$ triasilgliserol yang ketiga asam lemaknya jenuh, $12 \%$ triasilgliserol dengan dua asam lemak jenuh dan $4 \%$ triasilgliserol yang mempunyai satu asam lemak jenuh. Asam lemak yang menyusun minyak kelapa terdiri dari 
$86 \%$ asam lemak jenuh dan $14 \%$ asam lemak tidak jenuh. Tingginya asam lemak jenuh pada minyak kelapa menyebabkan minyak ini lebih tahan terhadap kerusakan oksidatif dibandingkan minyak lainnya. Berdasarkan kandungan asam lemak dominannya, minyak kelapa digolongkan sebagai minyak laurat, karena kandungan asam lauratnya paling besar dibandingkan dengan asam lemak lainnya, yakni antara 45,4-46,4\% (Mulyazmi, 2008).

Tujuan penelitian ini untuk mengetahui pengaruh ukuran serbuk biji nimba (A. indica) dalam minyak kelapa terhadap organoleptik.

\section{METODE PENELITIAN}

Penelitian ini merupakan penelitian eksperimental dengan desain kualitatif deskriptif. Penelitian dilakukan di Laboratorium Kimia Dasar, Prodi Farmasi, Fakultas Ilmu Kesehatan, Universitas Ibrahimy pada Bulan Februari-Agustus 2019.

Alat dan bahan yang digunakan pada penelitian ini antara lain toples plastik, beAker gelas, corong kaca, pipet, pengaduk, neraca, termometer, kompor listrik, kertas saring, gelas ukur, kertas lakmus, almumunium foil, plastik wrap, handscoon, stieve, minyak kelapa merek Barco, serbuk biji nimba, akuades.

Metode yang digunakan pada penelitian ini adalah metode ekstraksi maserasi dan infus minyak. Selanjutnya dilakukan uji organoleptik dengan parameter pengamatan warna (jernih dan tidak jernih), aroma (tengik dan tidak tengik) dan pengukuran $\mathrm{pH}$ menggunakan kertas lakmus dengan pengulangan sebanyak 7 kali. Data hasil dianalisis secara deskriptif kualitatif dan studi literatur dengan penyajian data berupa tabel hasil.

Tahapan penelitian ini meliputi pembuatan simplisia serbuk biji nimba, ekstrasi maserasi dan infus minyak, uji ornoleptik dan analisis data.

Pembuatan simplisia serbuk biji nimba dilakukan dengan mengkoleksi biji nimba secara manual yaitu mengambil secara acak biji nimba dari yang muda (hijau) hingga tua (kuning) dengan rata-rata diameter $2 \mathrm{~cm}$. Kemudian biji nimba dipisahkan dari sisa kotoran dan dicuci meggunakan air. Setelah itu, biji nimba dibelah menjadi dua secara melintang supaya mempercepat proses pengeringan. Selanjutnya biji nimba di jemur dibawah sinar matahari selam 3 hari 
(sampai biji kering), kemudian dihaluskan menggunakan mesin penggiling biji hingga berupa serbuk. Tahapan berikutnya serbuk biji nimba diayak menggunakan saringan atau stieve ukuran 20, 40 dan 80 mesh dan disimpan dalam toples plastik. Serbuk biji nimba dengan berbagai ukuran digunakan untuk tahapan selanjutnya.

Tahapan ekstraksi terdiri dari dua tahapan yaitu ekstraksi maserasi dan infus minyak. Perbandingan serbuk biji nimba dan pelarut adalah 1:3. Pada proses ekstraksi maserasi serbuk biji nimba ukuran 20, 40 dan 80 mesh ditimbang masing-masing sebanyak 25 gram dan di masukkan dalam cup plastik yang sudah diberi label. Kemudian dimasukkan minyak kelapa masing-masing $75 \mathrm{ml} \mathrm{ke} \mathrm{dalam} \mathrm{cup}$ plastik yang sudah terdapat serbuk biji nimba dan diaduk hingga larut. Selanjutnya, cup plastik ditutup dengan plastic warp, alumunium foil dan penutup cup plastik. Serbuk biji nimba yang telah direndam disimpan pada suhu ruang selama 24 jam. Tahap selanjutnya yaitu proses ekstraksi infus minyak. Pada tahap ini rendaman serbuk biji nimba dalam miyak kelapa dituangkan dalam beaker gelas dan dipanaskan menggunakan kompor listrik pada suhu $70-90^{\circ} \mathrm{C}$ selama 15 menit dengan pengadukan secara teratur. Selanjutnya didinginkan dan disaring menggunakan kain dan kertas saring yang diletakkan pada corong kaca.

Hasil rendaman serbuk biji nimba dalam minyak kelapa diperoleh minyak biji nimba yang selanjutnya dilakukan uji organoleptik sebagaimana dalam tabel berikut:

Tabel 1. Uji Organoleptik pada Kelompok Perlakuan dan Kontrol.

\begin{tabular}{lc}
\hline \multicolumn{1}{c}{ Perlakuan } & Volume \\
\hline Kontrol (minyak kelapa) & $75 \mathrm{ml}$ \\
Serbuk biji nimba 20 mesh & $25 \mathrm{gram}+$ \\
+ minyak kelapa & $75 \mathrm{ml}$ \\
Serbuk biji nimba 40 mesh & $25 \mathrm{gram}+$ \\
+ minyak kelapa & $75 \mathrm{ml}$ \\
Serbuk biji nimba 80 mesh & $25 \mathrm{gram}+$ \\
+ minyak kelapa & $75 \mathrm{ml}$ \\
\hline
\end{tabular}

Tahap selanjutnya yaitu uji organoleptik. Uji organoleptik yang dilakukan adalah mengamati dengan panca indra, yang diamati yaitu warna (jernih dan tidak jernih+, tidak jernih ++ , tidak jernih +++ ), sedangkan pengamatan aroma (tengik dan tidak tengik) dan pengukuran $\mathrm{pH}$ menggunakana kertas lakmus. Hasil dari uji organoleptik di analisis secara deskriptif kualitatif. 


\section{HASIL DAN PEMBAHASAN}

Hasil uji organoleptik pengaruh serbuk biji nimba (A. indica) dalam pelarut minyak kelapa menunjukkan adanya perbedaan pada warna minyak yang telah di ekstraksi dari pada kontrol (minyak kelapa), namun pada pengamatan aroma semua perlakuan dan kontrol tidak berbau tengik dan pada pengukuran $\mathrm{pH}$ semua sampel perlakuan dan kontrol memiliki $\mathrm{pH}$ yang sama yaitu 5 .

Tabel 2. Hasil Uji Organoleptik.

\begin{tabular}{|c|c|c|c|}
\hline \multirow{2}{*}{ Perlakuan } & \multicolumn{3}{|c|}{ Uji Organoleptik } \\
\hline & Aroma & Warna & pH \\
\hline $\begin{array}{l}\text { Kontrol } \\
\text { (minyak } \\
\text { kelapa) }\end{array}$ & $\begin{array}{l}\text { Tidsak } \\
\text { tengik }\end{array}$ & Jernih & 5 \\
\hline $\begin{array}{l}\text { Serbuk biji } \\
\text { nimba } 20 \\
\text { mesh }+ \\
\text { minyak kelapa }\end{array}$ & $\begin{array}{l}\text { Tidak } \\
\text { tengik }\end{array}$ & $\begin{array}{l}\text { Tidak } \\
\text { jernih } \\
+\end{array}$ & 6 \\
\hline $\begin{array}{l}\text { Serbuk biji } \\
\text { nimba } 40 \\
\text { mesh }+ \\
\text { minyak kelapa }\end{array}$ & $\begin{array}{l}\text { Tidak } \\
\text { tengik }\end{array}$ & $\begin{array}{l}\text { Tidak } \\
\text { jernih } \\
++\end{array}$ & 6 \\
\hline $\begin{array}{l}\text { Serbuk biji } \\
\text { nimba } 80 \\
\text { mesh }+ \\
\text { minyak kelapa }\end{array}$ & $\begin{array}{l}\text { Tidak } \\
\text { tengik }\end{array}$ & $\begin{array}{c}\text { Tidak } \\
\text { jernih } \\
+++\end{array}$ & 6 \\
\hline
\end{tabular}

Berdasarkan tabel 2 hasil uji organoleptik menunjukkan bahwa pada semua perlakuan dan kontrol menunjukan aroma bau yang tidak tengik. Hal ini disebabkan karena sampel yang digunakan adalah serbuk biji nimba yang sudah dikeringkan yaitu kadar air yang terkandung dalam sampel sudah sangat sedikit sehingga tidak menimbulkan aroma tengik. Sedangkan aroma minyak kelapa saja hampir tidak berbau.

Minyak kelapa mempunyai karakteristik bau spesifik, warna jernih atau kekuningan dan berbentuk cair pada suhu $24-26^{0} \mathrm{C}$. Bau yang spesifik tersebut banyak berhubungan dengan adanya sejumlah kecil $(<150 \mathrm{ppm}) \delta$ dan $\gamma$-laktam sebagai hasil reaksi oksidasi (Mulyazmi, 2008). Warna pada minyak kelapa disebabkan oleh zat warna dan kotoran-kotoran lainnya.Zat warna alamiah yang terdapat pada minyak kelapa adalah karoten yang merupakan hidrokarbon tidak jenuh dan tidak stabil pada suhu tinggi (Tambun, 2006). Minyak kelapa memiliki titik beku pada suhu di sekitar $70^{\circ} \mathrm{F}$ atau $21,1^{\circ} \mathrm{C}$ (Mursalin dkk, 2013).

Aroma pada minyak yang diberi serbuk biji nimba terdapat aroma minyak atsiri namun tidak tengik. Hal ini sesuai bahwa bau dan rasa minyak terutama ditimbulkan oleh senyawa teroksigenasi, yang biasanya lebih mudah larut dalam alkohol. Kebanyakan minyak yang memiliki aroma khas tersusun atas senyawa terpeneoid (Sukardiman, 2013). Pada biji nimba mengandung $60 \%$ minyak 
atau lemak dari asam stearat, palmitat, oleat, linoleat, laurat, butirat dan sejumlah kecil minyak atsiri (Alais, 1999).

Pada pengamatan warna perlakuan dan kontrol sangat terlihat jelas perbedaannya yaitu warna minyak kelapa sangat jernih, sedangkan pada perlakuan juga terdapat perbedaan warna. Pada perlakuan yang menggunakan serbuk biji nimba 20 mesh memiliki warna tidak jernih dengan warna hijau agak pekat (+). Hal ini bisa disebabkan karena jumlah senyawa yang larut dalam minyak lebih sedikit karena ukuran serbuk biji nimba lebih besar dan lebih sulit untuk larut dalam minyak kelapa. Sedangkan pada perlakuan serbuk biji nimba 40 mesh warnanya tidak jernih atau hijau pekat (++). Pada perlakuan serbuk biji nimba 80 mesh warnanya tidak jernih atau hijau pekat $(+++)$ hal ini disebabkan oleh ukuran serbuk yang lebih kecil sehingga mudah untuk larut.

Pengaruh ukuran partikel yaotu semakin kecil ukuran partikel, semakin besar luas bidang kontak antara padatan dan pelarut, serta semakin pendek jalur difusinya, yang menjadikan laju transfer massa semakin tinggi, sehingga terlihat jelas bahwa pada perlakuan serbuk biji nimba 80 mesh memiliki warna hijau pekat $(+++)$ paling pekat diantara semua sampel.

Faktor lain yang mempengaruhi kelarutan yaitu suhu. Pada penelitian ini dilakukan metode infus minyak yaitu pemanasan pada suhu $70-90^{\circ} \mathrm{C}$ selama 15 menit bertujuan untuk melarutkan senyawa yang ada pada serbuk biji nimba dan menurunkan tingkat viskositas minyak kelapa sehingga bisa senyawanya bisa berikatan dengan maksimal. Kelarutan bahan yang diekstraksi dan difusivitas biasanya akan meningkat dengan meningkatnya suhu, sehingga diperoleh laju ekstraksi yang tinggi. Pada beberapa kasus, batas atas untuk suhu operasi ditentukan oleh beberapa faktor, salah satunya adalah perlunya menghindari reaksi samping yang tidak diinginkan (Sukardiman, 2013).

Pada pengamatan $\mathrm{pH}$ jelas terdapat perbedaan kontrol dan perlakuan. Pada kontrol (minyak kelapa) memiliki pH 5 yaitu bersifat asam. Hal ini disebabkan karena minyak kelapa mengandung $84 \%$ triasilgliserol yang ketiga asam lemaknya jenuh, $12 \%$ triasilgliserol dengan dua asam lemak jenuh dan $4 \%$ triasilgliserol yang mempunyai satu 
asam lemak jenuh. Sedangakan pada perlakuan serbuk biji nimba 20, 40 dan 80 mesh memiliki pH 6 lebih tinggi dari pada minyak kelapa saja. Hal ini menunjukkan bahwa terdapat senyawa yang terikat. Senyawa yang paling dominan terdapat dalam biji nimba adala azadirachtin yang termasuk golongan triterpenoid dan bersifat non polar. Sedangkan minyak kelapa juga bersifat non polar sehingga dapat berikatan dan menyebabkan $\mathrm{pH}$ meningkat (Kristanti dkk, 2008).

\section{SIMPULAN DAN SARAN}

Berdasarkan hasil penelitian dan pembahasan terdapat pengaruh ukuran serbuk biji nimba (A. indica) dalam pelarut minyak kelapa terhadap uji organoleptik. Pada pengamatan warna perlakuan serbuk biji nimba 80 mesh memiliki warna tidak jernih $(+++)$ paling pekat dan kontrol (minyak kelapa) jernih. Hasil pengamatan aroma semua perlakuan dan kontrol tidak tengik. Pada hasil pengukuran $\mathrm{pH}$ semuanya bersifat asam yaitu kontol 5 dan semua perlakuan memiliki pH 6.

Saran pada
selanjutnya bisa

berbeda dalam mendukung uji organoleptik.

\section{DAFTAR PUSTAKA}

Alais C, Linden G. 1999. Food Biochemistry. Aspen Publisher, Inc., Gaithersbury, Maryland.

Kardinan, A., dan Ruhnayat, A., 2003. Mimba Budi Daya dan Pemanfaatan. Jakarta: Penebar Swadaya.

Kristanti, Alfinda Novi dkk. 2012. Fitokimia. Surabaya: Airlangga University Press.

Mulyazmi.2008. Pengambilan Asam Oleat dari Minyak Kelapa. Jurnal Teknos 2k. 8(2):60-66.

Mursalin, Purwiyatno, H., Eko, H.P., Nuri, A., dan Dedi, F. (2013).Fraksinasi Kering Minyak Kelapa Menggunakan Kristalisator Skala 120 Kg untuk Menghasilkan Fraksi Minyak Kaya Triasilgliserol Rantai Menengah. Jurnal Littri. 19(1): 41-49.

Pramudhito. 2010. Analis Profil Protein Ekstrak Aquadest Biji MimbA (Azadirachta indica Juss) dengan Pemanasan dan Tanpa Pemenanasan melalui Analisis SDS-PAGE. Skripsi. Jember: Fakultas Kedokteran Gigi Universitas Jember.

Sari, K.P dan Suharsono. 2014. Efikasi: insektisida nabati dalam mengendalikan kutu kebul, (Bemisia tabaci Genn). (Homoptera: Aleyrodidae). Widyariset. 17 (2): 219-266. 
Schmutterer, H. 1990. Properties and Potential of Natural Pesticides from Neem Tree, Azadirachta indica. Ann. Rev. Entomol. 35 : $271-295$.

Suhardiyono, L. 1995. Tanaman Kelapa. Jakarta: Kanisius. hlm. 128.

Sukardiman dkk. 2013. Buku Ajar Farmakognosi Jilid 1. Surabaya: Airlangga University Press.

Tambun, R. 2006. Buku Ajar Teknologi Oleokimia. Medan: Fakultas Teknik USU. hlm. 1-6, 12-14.

Thomson, W.T. 1992. Agricultural Chemicals. Book I: Insecticides. Fresno, CA: Thomson Publications.

Vinoth, B. dkk. 2012. Phytochemical analysis and antibacterial activity of azadirachta indica a juss. International journal of research in plant science. 2(3) 2012. 